\title{
Water resources of the Russian rivers and their changes
}

\author{
Mikhail Georgievsky \\ State Hydrological Institute, Saint-Petersburg, 199053, Russia \\ Correspondence to: Mikhail Georgievsky (mgeorgievsky@ hotmail.com) \\ Published: 17 October 2016
}

\begin{abstract}
This paper is a review of the recent investigations related to changes in river water resources of the Russian Federation performed at the State Hydrological Institute (SHI). The long-term water resources fluctuations and their changes during the last decades including the significant changes in seasonal runoff are presented. The preliminary estimates of the possible future changes are also given.
\end{abstract}

\section{Introduction}

Water resources of any country are a very important factor of its social and economic development. Water availability and deficits influence the rate and efficiency of water use. Russia is one of the most prosperous countries of the world with respect to renewable water resources. The country's renewable water resources amounted to $4270 \mathrm{~km}^{3}$ year ${ }^{-1}$ until the mid-1970s (Shiklomanov and Georgievsky, 2007), which represented about $11 \%$ of the global resources.

This paper summarizes the results of a study of changes in renewable water resources carried out by the SHI specialists. It should be emphasized that an assessment of the Russian water resources is a very complex task since there are about 2.5 million streams in the country while the hydrological network consists of only about 3100 observational stations at the moment. Therefore, the role of scientific hydrology, especially that of the studies of runoff formation processes for different physiographic regions and different sizes of watersheds, is very important. It is essential for generalization of the existing hydrological data and assessment of water resources for rivers and areas, where stationary hydrological observations are not available.

\section{River water resources of Russia and their long-term dynamics}

According to the SHI estimates (Shiklomanov, 2008), the average annual water resources of the Russian Federation amount to $4324 \mathrm{~km}^{3}$ year ${ }^{-1}$ including $4118 \mathrm{~km}^{3}$ year $^{-1}$ formed within the country and $206 \mathrm{~km}^{3}$ year ${ }^{-1}$ coming from the neighbouring states.

Distribution of the renewable water resources within Russia is very uneven. Their predominant part belongs to basins of the Arctic (70\% of river runoff) and the Pacific Oceans $(20 \%)$. There are only about $10 \%$ of the total river runoff resources in the Atlantic Ocean, the Black and the Caspian Sea basins where population density is the highest in the country.

The long-term dynamics of the Russian renewable water resources is presented in Fig. 1. As can be seen, rising temperatures have been accompanied by increase in renewable water resources since the late 1970s-early 1980s.

There were only three years $(1982,1987$ and 1992) with water resources insignificantly below the normal (19361980) during the past three decades. It is considered at SHI that there have been significant changes in water regime of the Russian rivers as a result of climate impacts since the early 1980s. Therefore, annual normal flows are basically defined over the period from the beginning of observations up to 1980 (conditionally stationary regime). The maximum volume of water resources observed previously in 1974 $\left(4706 \mathrm{~km}^{3}\right)$ was exceeded in 1990, 1997, 1999, 2002 and 2007 (see Fig. 1). The maximum water resources $\left(4875 \mathrm{~km}^{3}\right)$ for the entire observation period were observed in 2007.

The most significant increase of annual runoff occurred in the major rivers of the Arctic Ocean. The water resources of the Pechora, Yenisei and Lena rivers in 2001-2011 exceeded the normal by $11-13 \%$.

The total increase of the Russian water resources for 1981-2012 amounted to $211 \mathrm{~km}^{3}$ year $^{-1}$ on average, which is $5.0 \%$ higher than the increase for 1930-1980. The water 


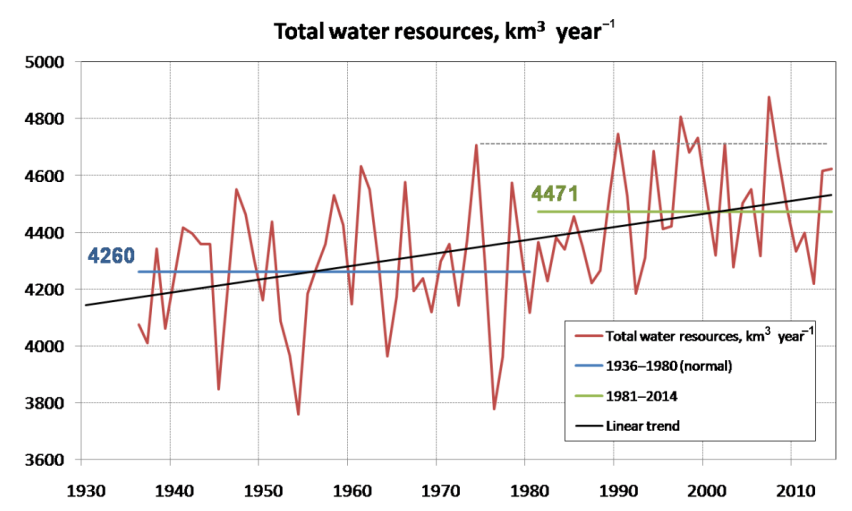

Figure 1. The long-term dynamics of renewable water resources of the Russian Federation.

resources increase was representative for all federal districts of Russia. The largest absolute increase was observed in the Siberian $\left(54.7 \mathrm{~km}^{3}\right.$ year $\left.^{-1}\right)$, Far Eastern $\left(50.8 \mathrm{~km}^{3}\right.$ year $\left.^{-1}\right)$ and North-western $\left(46.5 \mathrm{~km}^{3} \mathrm{year}^{-1}\right)$ Federal Districts, the smallest one in the Central $\left(9.9 \mathrm{~km}^{3} \mathrm{year}^{-1}\right)$ and Ural $\left(11.9 \mathrm{~km}^{3}\right.$ year $\left.^{-1}\right)$ Federal Districts. The largest relative runoff increase was observed in the Volga (13.5\%), Southern (including the North Caucasus) $(8.8 \%$ ), Central (7.9\%) and North-western $(7.7 \%)$ Federal Districts, the lowest one in the Ural (2.0\%) and Far Eastern (2.7\%) Federal Districts.

Thus, the data presented show that ongoing warming in Russia over the last decades has been accompanied by increase in water resources in relation to the previous long-term period (1936-1980).

\section{Changes in seasonal runoff}

The results of a comprehensive statistical analysis of seasonal and monthly runoff of rivers with a natural water regime led to the conclusion that the ongoing climate changes had a strong impact on the regime of winter and summer-autumn river flows.

The water content $\left(\mathrm{km}^{3}\right.$ year $\left.{ }^{-1}\right)$ of the majority of rivers over the largest part of the European Russia (hereinafter EPR) increased by $50-120 \%$. In addition, there are positive trends of winter runoff with significantly increased runoff variability. Such significant increase in winter flow observed over the last several decades demonstrates that the conditions for runoff formation have changed significantly as a result of ongoing global warming. This conclusion is also confirmed by the analysis of observational data of the ROSHYDROMET observation network (the water balance and wetland observation stations), as well as by physical and mathematical modelling of migration and infiltration of moisture in freezing and thawing soils (Gurevich, 2009; Kalyuzhnyi et al., 2012; Kalyuzhnyi and Lavrov, 2012; Zhuravin et al., 2012).
It was found out that the winter air temperature increase led to:

- a decrease in soil freezing depth with increase of its draining properties;

- an increase of number and duration of winter thaws during which both snowmelt and meltwater outflow from the snowpack occur;

- ground water recharge and surface runoff formation.

As a result, the river runoff during winter period increased and snow water equivalent before melting period was reduced, which created the conditions for decreased spring flood runoff.

In addition to the direct influence of thaws on the winter runoff, the processes of winter moisture migration and moisture accumulation in a frozen zone make a substantial contribution to the runoff increase during the cold period. The winter air temperature increase coupled with the decrease in soil freezing depth delay the permafrost processes in a catchment which promotes the growth of the winter runoff. Higher air temperature also lead to a decrease of runoff withdrawals from a streamflow required for ice formation and increase the stream hydraulic conductivity, which is also important factor in increasing of low flows during the cold season (Gurevich, 2009; Lavrov and Kalyuzhnyi, 2012).

The increase of summer-autumn runoff in 1978-2012 was observed over most of the Russian regions. These anomalies are most clearly manifested in rivers of the southern part of the forest zone and in the forest-steppe and steppe zones of the EPR. In these regions, the summer-autumn runoff during 1978-2012 was higher in comparison with the previous period (1946-1977) by 40-70\% on average with increased runoff variability. Over the Asian part of Russia (APR), the winter runoff increase (up to $40 \%$ ) occurred in the Lena river and the Northeastern rivers (Olenek, Yana and Indigirka).

The spring flood runoff changes in various regions of the country are diverse. In the rivers of the Baltic Sea basin, the Volga (except for northern and north-eastern parts of the river), Don, Dnieper and Upper Ob river basins, the spring runoff was reduced by $10-30 \%$ in the recent decades. The dispersion of spring runoff decreased overmost parts of these rivers. The spring flood flow reduction was due to a decrease in snow water equivalent by the beginning of the snowmelt period as a result of the increase in the number and duration of thaws during the cold season. The spring flood runoff increase was observed in the Kama basin. This applies for most of the EPR's rivers which belong to the Arctic Ocean basin, in the Lena, Yana and Indigirka river basins and over the northern part of the $\mathrm{Ob}$ and Yenisei basins.

\section{Conclusions and possible future changes}

Summarizing the results and analysing the long-term river water recourses fluctuations in Russia the following conclu- 
sions can be formulated. The main feature of the modern water regime changes in most parts of the country is due to a significant increase in water content during low-flow periods, especially during the winter months in the past 30 years. There are positive trends of increase in winter and summerautumn low-flow for most rivers considered within the major regions of Russia. The observed "synchronization" of low flow changes (especially winter runoff) for large country areas and the scale of these changes are extraordinary and have no analogues in the 20th century. The low flow growth caused an increase in water resources during 19802010 even in river basins where the decrease of spring flood runoff took place. The analysis of observational data over the last hundred years allow us to conclude that such a situation happened for the first time since previously all significant low and high water phases were determined primarily by the magnitude of spring flood runoff.

A precise forecast of future water resources in several decades is required for the purposes of water supply planning as well as for the justification of major water economic practices for river runoff control, its intra basin and territorial re-distribution. Taking into account that climate change is a reality, a methodology of these assessments should be based on results of an analysis of regional river runoff changes and data on future climate scenarios generated by the Coupled Atmosphere-Ocean General Circulation Models.

In accordance with the assessments made at SHI (Georgievsky and Shalygin, 2012; Shiklomanov et al., 2008), there is no reason to expect any significant changes in water resources of the main Russian rivers as a result of climate warming in the coming decades. Over most parts of the country an insignificant increase in annual runoff within its natural variability (within $5 \%$ ) will probably be observed.

However, the most problematic regions in terms of water availability were identified based on the assessments. These are the Don basin in the EPR and the upper part of the $\mathrm{Ob}$ basin in the APR. There is a possibility of water resources decrease in these basins as a result of climate change which must be taken into account in advance in water supply planning.

Regarding possible future changes in seasonal river runoff it is expected that the identified tendencies based on the observational data will remain. There will be an increase in winter runoff which will require adaptation efforts including revision of water reservoirs management system.

\section{Data availability}

The data relating to the water resources of the Russian Federation are taken from the annual illustrated guides "Water Cadastre of the Russian Federation. Use and quality of surface and ground water resources" which have been published (in Russian) by ROSDYFROMET in cooperation with ROSVODRESURSY and ROSNEDRA since 1981. These guides are publically accessible and present the results of the assessments of water resources of the Russian Federation, its federal districts as well as the largest and most important river basins from economic and ecological perspectives. The data relating to Sect. 3 "Changes in seasonal runoff" are individual data of the SHI specialists cited in this article.

\section{The Supplement related to this article is available online at doi:10.5194/piahs-93-75-2016-supplement.}

Acknowledgements. The author is grateful to all colleagues of the State Hydrological Institute whose materials and publications were used in this article.

\section{References}

Georgievsky, V. Yu. and Shalygin, A. L.: Hydrological regime and water resources, in: Methods for Assessing Climate Change Impacts on Physical and Biological Systems, Chapter 2, Moscow: Rosgidromet, 53-86, 2012.

Gurevich, E. V.: Influence of air temperature on the river runoff in winter (the Aldan river catchment case study), Russian Meteorology and Hydrology, 34, 628-633, 2009.

Kalyuzhnyi, I. L. and Lavrov, S. A.: Basic physical processes and regularities of winter and spring river runoff formation under climate warming conditions, Russ. Meteorol. Hydrol., 37, p. 44, 2012.

Kalyuzhnyi, I. L., Lavrov, S. A., and Romanyuk, K. D.: Variations in Water Regime of Bogs in Northern and Northwestern Russia under the Effect of Climatic Factors, Water Resources, 39, 1322, 2012.

Lavrov, S. A. and Kalyuzhnyi, I. L.: Physical Processes and Regulation Concerning the Volga River Basin Rivers Winter and Spring Runoff Formation in the Conditions of Climate Change, Water Sector of Russia, 4, 74-84, 2012.

Shiklomanov, I. A. and Georgievsky, V. Yu.: Current and future river runoff changes in Russia under the influence of climatic factors, in: Inland waters in a changing climate, St. Petersburg, Nauka, 20-32, 2007.

Shiklomanov, I. A., Georgievsky, V. Yu., Shalygin, A. L., Georgievsky, M. V., Golovanov, O. F., and Shiklomanov, A. I.: Water resources: predictive estimates, in: Water resources of Russia and their use, edited by: Shiklomanov, I. A., Chapter 11.2, 442-464, 2008.

Zhuravin, S. A., Kaliuzhny, I. L, Lavrov, S. A., Rakcheyeva, E. A., and Gaponov, I. N.: Hydrological response to climate variability in European mixed forest zone (Podmoskovnaya WBS case study), in: Studies of Hydrological Processes in Research Basins: Current Challenges and Prospects, 14th Biennial Conference ERB 17-20 September 2012, St. Petersburg, Russia, Book of Abstracts, 19-22, 2012.

Shiklomanov, I. A. (Ed.): Water resources of Russia and their use, St. Petersburg, State Hydrological Institute, 600 pp., 2008. 